\title{
Jednodětnost $\mathrm{v}$ českých rodinách. Kdo jsou ti, kdo mají nebo plánují pouze jedno dítě*
}

\author{
LADISLAV RABUŠIC, BEATRICE-ELENA CHROMKOVÁ MANEA** \\ Fakulta sociálních studií Masarykovy univerzity, Brno \\ One-child Families in the Czech Republic. \\ Who Are the People Who Have or Plan to Have Just One Child?
}

\begin{abstract}
The article tackles the phenomenon of the one-child family in the Czech Republic. The authors try to answer the question of whether it is possible to expect that a significant proportion of Czech fertility intentions will be fulfilled when families conceive and give birth to an only child. Can it be assumed that one-child families will be a significant phenomenon in Czech society in the years to come? To answer the questions the authors used two different datasets in the analysis. The article includes a description of the socio-demographic characteristics of people who have or intend to have just one child. They then proceed to present some of the covariates that determine whether people have or intend to have one child in comparison with those who have other fertility intentions. Some of the findings indicate that it is likely that about $20-25 \%$ of women who finish their reproductive period within the next two decades will have only one child. The results indicate that being an only child increases the chances of intending to and having only one child. The opposite effect can be noticed when the place of residence is considered - living in small towns and rural areas may have a negative influence on the decision to have only one child.
\end{abstract}

Keywords: one-child family, fertility intentions, reproductive behaviour, fertility determinants, expected fertility, Czech society.

Sociologický časopis/Czech Sociological Review, 2007, Vol. 43, No. 4: 699-719

\section{1. Úvod}

Česká republika zažívá v posledním desetiletí nízkou plodnost jako nikdy ve své historii. Hodnoty úhrnné plodnosti se pohybovaly mezi 1,2-1,3 dětí na ženu, což je intenzita, která je označována jako extrémně nízká plodnost. Analýzy se sho-

\footnotetext{
* Výzkum pro tento článek byl finančně podporován Grantovou agenturou České republiky (GA ČR), grant č. 403/05/0800 „Rodina, práce a reprodukční strategie v České republice“ a grantem Ministerstva školství, mládeže a tělovýchovy ČR - výzkumný záměr „Reprodukce a integrace společnosti“ (MSM002 1622408). Děkujeme dvěma anonymním recenzentům za jejich velmi konstruktivní připomínky.

** Veškerou korespondenci posílejte na adresu: prof. PhDr. Ladislav Rabušic, CSc., katedra sociologie, Fakulta sociálních studií Masarykovy univerzity, Joštova 10, 60200 Brno,
} 
dují na tom, že momentální propad plodnosti je z velké části způsoben odkládáním početí [Sobotka 2003] a že tedy stále existuje jistá naděje, že toto odkládání početí do vyššího věku žen nepovede k celkově výrazně nižší konečné plodnosti příslušné věkové kohorty, byt' jisté analytické signály, že tomu tak může být, již máme [Hamplová, Rychtaříková, Pikálková 2003].

Sociologické a demografické výzkumy naznačují, že v Česku došlo po roce 1989 ke změně populačního klimatu, kdy demografický režim bývalé společnosti reálného socialismu charakteristický časnými sňatky a porody, krátkými meziporodními intervaly a celkovou vyšší plodností, je nahrazován režimem, pro nějž je typická nízká sňatečnost, existence nesezdaných soužití, nárůst podílu celoživotně bezdětných osob, porod v pozdějším věku a snižování porodů vyššího pořadí.

O příčinách této proměny se zatím pouze dohadujeme. Je zřejmé, že v pozadí změn stojí kulturní, sociální a ekonomický kontext nové české společnosti, který přesunul hodnotové priority mladé populace od "rodinné ideologie", tedy familiarismu, ${ }^{1} \mathrm{k}$ prioritám individualismu, sebenaplnění a jistého hedonismu. $\mathrm{V}$ tomto kontextu je samozřejmě klíčovou otázkou, nakolik mladé ženy a mladí muži potřebují ke svému citovému a psychickému uspokojení mít děti. V současných moderních společnostech existuje tolik prvků a fenoménů, které dokáží přinášet jedincům a párům pocit naplnění a uspokojení jejich potřeb, že vytvářejí velmi silnou konkurenci „potřebě mít děti“. Lze vyslovit domněnku, že právě díky novým hodnotovým prioritám bude v české společnosti narůstat podíl těch, kteří si budou přát (a toto přání budou také celoživotně realizovat) pouze dítě jedno. ${ }^{2}$

Z posledního sčítání lidu v ČR v roce 2001 vyplývá, že podíl žen ve věkových skupinách 40-44, 45-49, 50-54 (jsou to tedy ženy narozené v období 1947-1961), které během svého života porodily jedno dítě, se pohyboval kolem 15 \%. Ve věkové skupině žen ve věku 35-39 let, tedy žen narozených v letech 1962-1966, byl ovšem podíl s jedním dítětem již 19 \%. Ačkoliv se jedná o ženy, které by ještě teoreticky mohly porodit další dítě, ze vzorce specifické plodnosti víme, že u této skupiny je to pravděpodobnost zatím poměrně nízká - $\mathrm{v}$ roce 2005 byla její specifická plodnost 23 dětí na 1000 žen. Je tedy možné považovat tento nárůst v podílu žen s jedním dítětem za signál, že jednodětnost je v ČR na vzestupu?

e-mail: rabu@fss.muni.cz a Beatrice-Elena Chromková Manea, M.A., katedra sociologie a Institut pro výzkum reprodukce a integrace společnosti, Fakulta sociálních studií Masarykovy univerzity, Joštova 10, 60200 Brno, e-mail: manea@fss.muni.cz.

${ }^{1}$ Možný konceptualizuje familiarismus jakožto takové vidění světa, „pro něž je rodina osou a centrem univerza jednotlivce i života společnosti a její blaho přirozeným cílem snažení všech“ [Možný 1991: 11].

${ }^{2}$ Rychtař́ková [2003] např. zastává názor, že ženy patřící ke generaci 70. letech budou rodit později než jejich matky, což vede $\mathrm{k}$ odkládání mateřství, $\mathrm{k}$ nárůstu podílu bezdětných žen a poklesu plodnosti druhého pořadí - a také $\mathrm{k}$ nárůstu rodin s jedním dítětem, dodejme. 
Důvodů pro hypotézu o narůstání jednodětnosti lze nalézt několik: (1) Pro současné meritokratické společnosti je typické, že manželé či partneři, kteří mají děti, jsou současně plně napojeni na trh práce (nebo se o to, v př́ípadě nezaměstnanosti, intenzivně snaží). Jedno dítě mưže být v tomto případě východiskem pro skloubení požadavků světa práce a citového světa sdílení, pokračování a transgrese. Navíc ženy mohou mít dojem, že mít pouze jedno dítě jim dává lepší pozici na trhu práce a zajištuje lepší pracovní př́iležitost. (2) Mít jen jedno dítě by mělo umožnit zažívat vše, co souvisí s rodičovstvím, aniž by docházelo k výraznému omezení obvyklých a preferovaných aktivit. (3) Omezení se pouze na jedno dítě může být vědomým rozhodnutím zajistit dítěti náležitou kvalitu života a zlepšit jeho životní šance v kompetitivním světě - což by se v případě, kdy by v rodině bylo ještě druhé, popř. třetí dítě, nemuselo podařit. (4) Partneři či manželé mohou mít výrazně odlišné představy o počtu svých dětí, takže se nakonec kompromisně dohodnou pouze na jednom [viz Voas 2003]. (5) Svobodné ženy, které netouží po sňatku, avšak chtějí mít dítě, mohou naplnit své "mateřské touhy" jedním a pouze jedním dítětem. (6) Z důvodů odkládání početí a z něj vyplývající snížené fekundity páru ve vyšším věku se může stát, že se rodičům podaří počít pouze jedno dítě. (7) Ve vysoce rozvodových společnostech - a ta česká takovou je - se může stávat, že po porodu prvního dítěte, který dnes nastává ve vyšším věku ženy, se manželství nebo partnerství rozpadne a žena se již pro další dítě nerozhodne. (8) Partneři po porodu prvního dítěte mohou odkládat své rozhodnutí mít další dítě, až nakonec u nich převládne pocit, že jsou na další rodičovství již staří. (9) Rodiče mohou mít špatné zkušenosti s těhotenstvím nebo s výchovou svého prvního dítěte, a proto se pro další dítě již nerozhodnou.

Můžeme tedy očekávat, že značná část porodnosti bude v ČR naplňována pouze porody jednoho dítěte? Že jednodětnost se stane naším výrazným populačním fenoménem? V našem příspěvku se pokusíme na tuto otázku odpovědět. Odpovědi budeme hledat prostřednictvím dvou druhů datových zdrojů. Jednak ze zdrojů demografické statistiky, jednak z údajů datových souborů, které zkoumaly české populační klima (byl to výzkum PPA II z roku 2001 a výzkum Žena, práce rodina z roku 2005) - ty nám umožní popsat, jak se ti, kdo mají či plánují pouze jedno dítě, liší svými socio-demografickými charakteristikami od těch, kdo mají jiné natalitní záměry.

\section{Východiska}

V našem článku se budeme při rozboru jednodětnosti částečně opírat o natalitní plány. Je samozřejmě velkou otázkou, do jaké míry se natalitní plány odlišují od samotné realizace, zdali plánované počty dětí jsou také skutečně v prủběhu života naplňovány a realizovány. Empirické studie nepřinášejí jednoznačnou odpověd'.

Zatímco na úrovni agregovaných dat některé analýzy vykazují pozoruhodnou shodu mezi natalitními plány a jejich následnou realizací [viz např. Cliquet 
et al. 1992; Monnier 1987; Westoff 1990; Quesnel-Vallée, Morgan 2003], na úrovni výběrových šetření (a tedy primárních dat) mnohé studie opakovaně zaznamenaly poměrně slabou korespondenci mezi plány na určitý počet dětí a počtem dětí skutečným - plány byly obvykle značně vyšší než skutečnost [viz např. Noack, Østby 1985, 2002; Bracher, Santow 1991; Van Peer 2002].

Jak lze nalézané rozdíly mezi dětmi plánovanými a realizovanými interpretovat? Rozpor mezi skutečnou plodností a plodností plánovanou nazývá Bongaarts [2001] novým a dosud plně neprozkoumaným fenoménem. Lze vyslovit domněnku, že diskrepance mezi plány a skutečností je zcela pochopitelná, nebot́ natalitní intence jsou de facto postoji a postoje se, jak známo, mohou měnit. Plodnost by pak v této perspektivě byla vnímána jako dynamický proces životní dráhy, kdy původní plány na počet dětí se díky neočekávaným událostem v životě páru postupně mohou proměnit. Ukazuje se navíc, že plány na výsledný počet dětí podléhají sekvenčním úpravám, kdy jsou reflektovány a znovu přezkoumávány s každým narozeným dítětem.

Na druhé straně jsou autoři, kteří tvrdí, že rozdíl mezi dětmi plánovanými a realizovanými je indikátorem nenaplněné potřeby (unmet need) jakožto důsledku nepříznivých sociálních a ekonomických okolností a nedokonalých opatření rodinné politiky [např. Chesnais 1998; Hakim 2003]. Jiné vysvětlení by mohlo poukazovat na fakt, že nalézané rozdíly mezi plány a skutečností jsou výsledkem dotazovací (výzkumné) situace, v níž respondenti mají tendenci dávat sociálně přijatelné odpovědi. Anebo jak tvrdí Voas [2003], je tato diference výsledkem vlivného mechanismu, kdy partneři (rodiče) se natolik liší ve svých plánech na konečný počet dětí, že je musí po vzájemném vyjednávání korigovat. Data z některých výzkumů tento efekt potvrzují. Jak na datech z mezinárodního výzkumu Family and Fertility Survey (FSS) ukázala Van Peerová [Van Peer 2002], stupeň shody v počtu plánovaných dětí u ženy a jejího partnera je faktorem, který významně přispívá $\mathrm{k}$ tomu, že tyto plány žena také skutečně realizuje [viz také Bracher, Santow 1991]. Mějme tuto různorodou interpretaci na paměti.

Zkoumání rodin s jedním dítětem bylo dlouhou dobu na okraji zájmu sociologie, demografie i př́ibuzných disciplín. V odborné literatuře zatím neexistuje obecně sdílený rámec teoretických poznatků o tom, proč se partneři nebo manželé rozhodují pouze pro jedno dítě, jaké mají charakteristiky a jaké jsou jejich životní preference a hodnoty. Rodiny s jedním dítětem jsou v literatuře často zmiňovány pouze v kontextu obecnějších teorií o nízké plodnosti nebo v kontextu teorií o vyjednávání, jak velká má rodina být. Pohledu na jednodětnost dominuje psychologie, která se o ni zajímá z hlediska jedináčkovství.

Hledání v literatuře na téma jednodětnosti nás velmi často přivede $\mathrm{k}$ tématu čínské populační politiky jednoho dítěte. ${ }^{3}$ Značná část článků a studií se zabývá čínskou státní rodinnou politikou („rodina s jedním dítětem“) a popisuje fenomén z demografické, sociální a psychologické perspektivy. Falbo a Dudley [1990,

\footnotetext{
${ }^{3}$ I první z autorů se tímto tématem kdysi parciálně zabýval [viz Rabušic 1987, 1988].
} 
1993] nebo Polit a Falbo [1987] studovali vývoj čínských dětí (jedináčků) a jejich výkon v oblasti vzdělání a v osobním životě z psychologického pohledu.

Daniele Lauferová [Laufer 1999] se ve své knize Enfants uniques: Des petites familles sous le regard des autres pokouší zodpovědět otázku, zdali být jedináčkem je „neobyčejné dobrodružství", nebo ne. Stávají se jedináčci sobeckými, nesdílnými, osamělými či smutnými? Nebo jsou sebevědomí a více milovaní? Mưžeme je poznat na ulici nebo ve společnosti? Jací jsou jejich rodiče - ti, kteří se rozhodnou mít jedno dítě? Její kniha obsahuje několik rozhovorů s lidmi, jež mají jedno dítě nebo jsou jedináčky. Autorka uvádí, že rozhodnutí mít jedno dítě je výsledkem komplexního vyjednávání mezi protikladnými zájmy v zaměstnání a rodinném životě a odpovědí na ekonomické poměry rodiny v modernitě. Lidé a zvláště ženy se nechtějí vzdát ani své profese, kariéry a zaměstnání, ani mateřství a role matky.

Nedávné studie ve Velké Británii a Rusku se pokusily načrtnout vývoj rodiny s jedním dítětem a její charakteristiky [viz Avdeev 2001; Jefferies 2001]. Ačkoli tyto dvě studie jsou spíše popisem daného fenoménu než detailní analýzou, považujeme za přínosné prezentovat některé z jejich nejdůležitějších výsledků. Cílem Jefferiesové bylo zjistit, jestli faktory spojené se záměrem mít jedno dítě (či jeho realizací) jsou podobné nebo odlišné od těch, které se pojí s odmítáním dětí. Její výsledky ukázaly, že věková kohorta, věk při prvním manželství a zkušenosti s manželstvím silně korelují s pravděpodobností, že rodiče budou mít jen jedno dítě, zatímco vzdělání hraje velmi malou roli. Dalším důležitým zjištěním bylo, že socioekonomické proměnné byly pro záměr mít druhé dítě jen slabými prediktory. Mít jedno dítě se podle Jefferiesové jeví jako vhodné řešení pro ty, kteří chtějí být rodiči a stále pracovat, budovat kariéru nebo mít volný čas. Jedním z hlavních důvodů, proč se lidé rozhodují mít více než jedno dítě, je všeobecná pozitivní percepce vícečlenných rodin - rodina se dvěma dětmi je ve Velké Británii stále považována za ideální model [Jefferies 2001].

Model vícečetné rodiny je stále preferován i v USA, nicméně jak zjištúují Hagewenová s Morganem [Hagewen, Morgan 2005], normy směřující proti jednodětným rodinám se v Americe postupně oslabují.

Další článek věnovaný rodinám s jedním dítětem pochází z Ruska [viz Avdeev 2001]. Analýza ukazuje, že pokles plodnosti zaznamenaný v současném Rusku není determinován pouze rozhodnutím odložit porod na pozdější dobu. Vysvětlení pro pokles je třeba hledat $\mathrm{v}$ přechodu od modelu rodiny se dvěma dětmi k rodině s jedním dítětem, který je podle Avdeeva způsoben ekonomickými faktory spojenými s politickými změnami - chápe je jako nejdůležitější determinanty poklesu plodnosti v Rusku a přijetí modelu rodiny s jedním dítětem.

Vidíme, že existující zahraniční literatura nám toho mnoho o tom, proč se lidé rozhodují mít jen jedno dítě, nenapoví. V České republice, pokud je nám známo, se tímto problémem, tedy kdo jsou lidé, kteři mají pouze jedno díté, a proč, zatím nezbýval nikdo. Proto jsme se rozhodli, že se pokusíme nalézt některé z faktorů ovlivňujících rozhodnutí mít jen jedno dítě. Analýza prezentovaná v následu- 
jících oddílech je především povahy deskriptivní a explorační, takže poskytuje předběžný pohled na demografické a socioekonomické činitele týkající se rodiny s jedním dítětem nebo plánující mít jen jedno dítě ve srovnání s rodinami se dvěma nebo více dětmi.

\section{Trendy plodnosti v České republice - stručný přehled}

Zkusme nejdříve naše úvahy o jednodětnosti spojit s existujícími demografickými daty. Na grafu 1 jsou uvedeny podíly žen ve věku 40 a více let, tedy ženy, které již ukončily svou biologickou reprodukci podle počtu dětí v roce 1991 a 2001. ${ }^{4}$ Data pocházejí ze sčítání lidu.

Vidíme, že proporce žen s jedním dítětem se ve sledovaných letech pohybovaly kolem 17-18 \%. Z těchto údajů tedy nevyplývá, že by fenomén jednodětnosti měl vzestupnou tendenci, což neodpovídá naší hypotéze. Tu však není třeba ještě zamítat, nebot' struktura konečné plodnosti žen, kterou data na grafu 1 reprezentují, stále ještě zachycuje efekty minulého demografického režimu. Výpočet pro rok 1991 je proveden z údajů o plodnosti žen, které se narodily v období 1920-1951, pro rok 2001 pak z období 1930-1961, je to tedy období plodnosti, které se odehrávalo na pozadí nejdřive tzv. budování socialismu a potom reálného socialismu - v podmínkách tzv. starého demografického režimu.

Abychom si udělali představu, zdali českých jednodětných rodin je mnoho nebo málo, srovnejme je s některými evropskými zeměmi (viz tabulku 1). Vycházíme z údajů, které ve svém článku poskytují Frejka a Sardon [2007].

Z tabulky 1 je patrné, že v kontextu srovnávaných zemí je český podíl jednodětných rodin u kohorty 1955 spíše nižší. Pro doplnění uved'me ještě data, která prezentuje ve své stati Jefferiesová [Jefferies 2001], když srovnává Velkou Británii s Francií. Zatímco v Británii v kohortě narozené v roce 1955 má jedno dítě $12 \%$ žen a $17 \%$ zůstává bez potomků, ve Francii tvoří bezdětné ženy pouze $8 \%$ ze všech žen narozených v roce 1954, přičemž $20 \%$ žen stejné kohorty má jedno dítě. Nalezené rozdíly pramení podle Jefferiesové z postojů lidí k bezdětnosti a $\mathrm{k}$ rodinám $\mathrm{s}$ jedním dítětem, současně ale souvisí se socioekonomickou situací a podmínkami, které ženy v manželství mají. Velká Británie má liberálnější postoje k bezdětnosti než Francie, kde naopak mít jedno dítě se považuje za lepší než zůstat bezdětný. Tento jev je poměrně častý např. v jižní Evropě, kde $26 \%$ Portugalek a 22 \% Španělek, které patří do skupiny narozených v roce 1955, má jen jedno dítě [Jefferies 2001].

Jefferiesová také uvádí, že podle provedených výzkumů hodlá mít jen jedno dítě méně žen, než kolik jich pak ve skutečnosti v populaci je. V ČR Hamplo-

\footnotetext{
${ }^{4}$ Ačkoliv pro konečnou plodnost demografové standardně pracují s věkem nad 45 nebo 49 let, pro Česko byla až dosud věková hranice 40 let u žen adekvátní, nebot’ po 40. roce věku se v minulých desetiletích rodilo první dítě jen minimálně. Sobotka [2006] uvádí, že po čtyřicítce tvořily míry plodnosti prvního pořadí pouhých $0,4 \%$.
} 
Graf 1. Podíl žen ve věku 40 a více let podle počtu živě narozených dětí v ČR

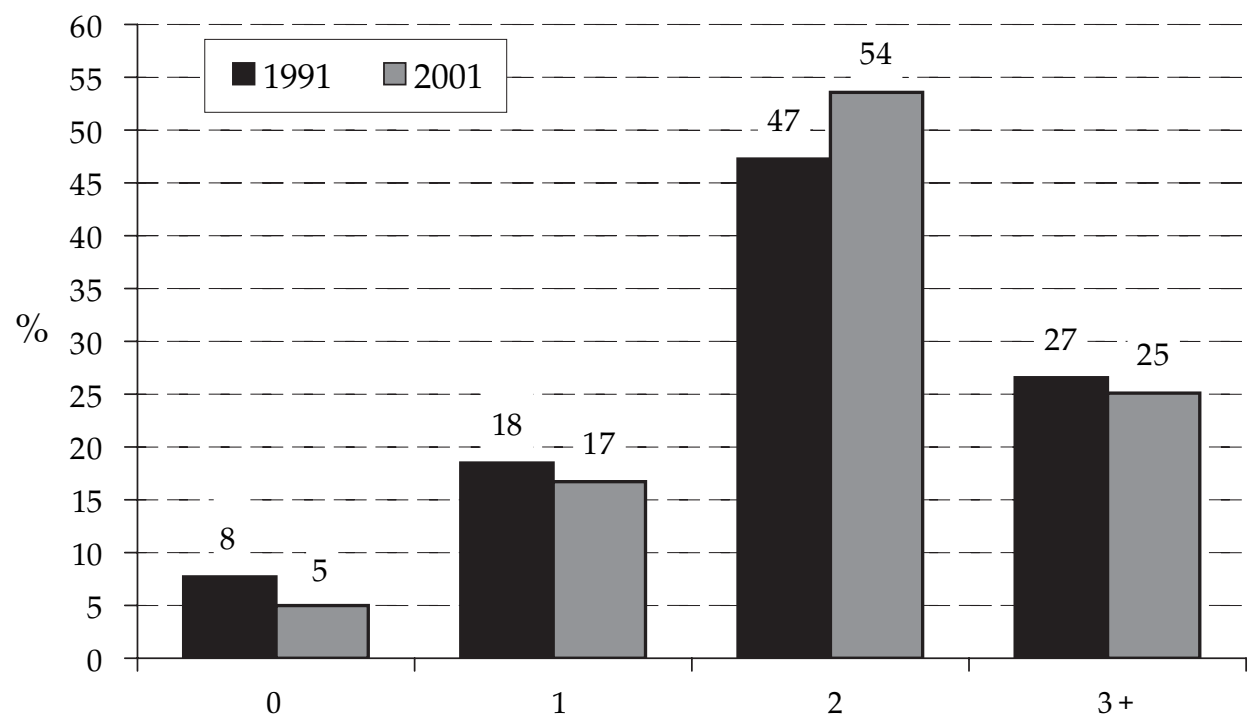

Zdroj: data ze sčíńní lidu z roků 1991 a 2001.

Tabulka 1. Struktura dětí podle pořadí u kohorty narozené v roce 1955 (v \%) $\mathrm{v}$ některých zemích

\begin{tabular}{|c|c|c|c|c|c|c|}
\hline \multirow{2}{*}{ Země } & \multicolumn{5}{|c|}{ Pořadí } & \multirow{2}{*}{$\begin{array}{l}\text { Úhrnná } \\
\text { plodnost } \\
\text { kohorty }\end{array}$} \\
\hline & 0 & 1 & 2 & 3 & 4 a více & \\
\hline Anglie a Wales & 17 & 12 & 40 & 20 & 10 & 2,02 \\
\hline Česká republika & 6 & 14 & 55 & 19 & 6 & 2,07 \\
\hline Nizozemsko & 17 & 15 & 43 & 18 & 7 & 1,87 \\
\hline USA & 16 & 18 & 35 & 19 & 11 & 1,99 \\
\hline Dánsko & 12 & 19 & 46 & 17 & 5 & 1,84 \\
\hline Rumunsko & 9 & 22 & 38 & 15 & 16 & 2,27 \\
\hline Španělsko & 11 & 22 & 44 & 23 & $--^{*}$ & 1,90 \\
\hline Itálie & 12 & 24 & 42 & 15 & 5 & 1,80 \\
\hline Portugalsko & 7 & 26 & 44 & 22 & $--^{*}$ & 1,96 \\
\hline
\end{tabular}

Pozn.: * údaje za 4 a více dětí nejsou $\mathrm{k}$ dispozici. Jen za 3 a více dětí.

Zdroj: [Frejka, Sardon 2007 table 7: 349-350]; "[Jefferies 2001: 3] a Internetová databáze Eurostatu http://epp.eurostat.ec.europa.eu. 
Graf 2. Podíly žen podle počtu živě narozených dětí v ČR v roce 2001 a podle roku narození: věková skupina 30-51 let

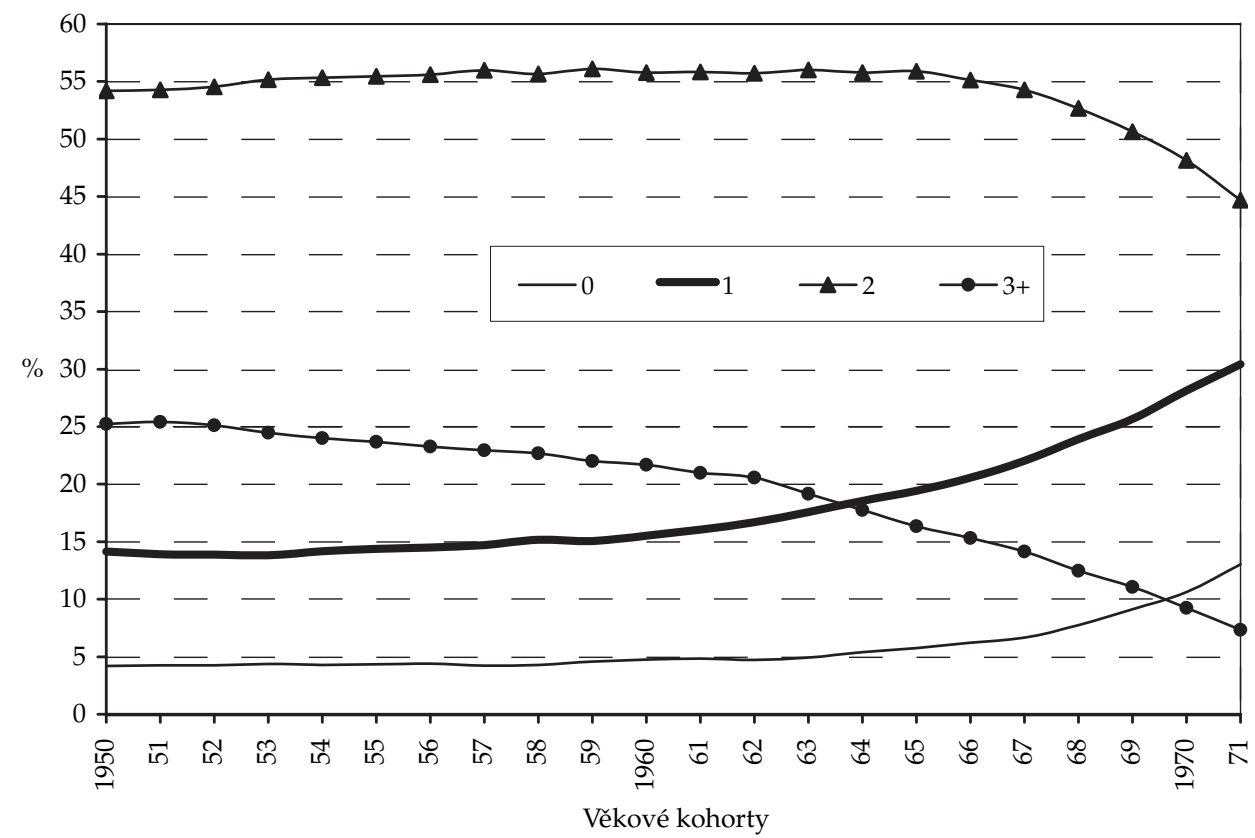

Zdroj: data ze sčítání lidu z roku 2001.

vá [2000] analyzovala vztah mezi ideálním a plánovaným počtem dětí na základě údajů z výzkumu „Mladá generace“ provedeného v roce 1997. Autorka zjistila, že jedno dítě jako ideální počet dětí uvedlo jenom $9 \%$ respondentů, přičemž nejčastěji to byli mladí lidé, kteří chtěli žít bez partnera nebo trvale v nesezdaném soužití. Důvody, které vedly k plánování jednoho dítěte, byly finance, osobní důvody a lepší podmínky pro výchovu.

Poněkud jiný pohled na demografické trendy přináší graf 2, na němž je struktura plodnosti žen, které se narodily v období 1950-2001; jsou to tedy ženy ve věku 51-30 let. Tento graf již signalizuje předpokládaný nárůst podílu žen s jedním dítětem. Jedno dítě mělo 19-20\% žen, jimž bylo v roce 2001 kolem 35 let (narodily se v období 1965-1967). Třicetiprocentní podíl žen s jedním dítětem, který vidíme na konci grafu u třicetiletých žen, pravděpodobně nezůstane zachován, část $\mathrm{z}$ nich asi porodí ještě další dítě nebo děti. Příslovce pravděpodobně je zde velmi namístě. Skutečně nemůžeme vědět, pro jak velký podíl z těchto žen to je cílový počet dětí; nemůžeme také vědět, zdali nižší schopnost početí, která se začíná objevovat po třicítce a která podle lékařů dynamicky narưstá po 35. roce věku, nesehraje svou roli a neomezí jejich další plodnost. 
Na jasnější posouzení trendu v jednodětnosti si tak budeme muset ještě určitou dobu počkat, určitější představu bychom mohli mít kolem roku 2015, kdy budou končit své období reprodukce kohorty žen narozené po roce 1970, které jsou již nositelkami nového reprodukčního režimu. Bude to také doba, během níž bude pomalu končit dynamické přesouvání porodů do vyššího věku žen a kdy se také u nás usadí nový reprodukční režim. Dříve než tato doba nastane, pokusme se o odhad možného vývoje trendu. Budeme jej formulovat na základě analýz výběrových šetření. Jejich výsledky přinášejí další části našeho příspěvku.

\section{Data z výběrových šetření a výsledky}

V tomto příspěvku využíváme pro analýzy data ze dvou studií: (a) Z výzkumu „Populační politika a veřejnost", který byl proveden jakožto reprezentativní výzkum v roce 2001. ${ }^{5}$ Výběrový soubor o velikosti 1073 respondentů zahrnoval občany České republiky ve věku nad 18 let. V našich analýzách používáme pouze podsoubor žen ve věkové kategorii 20-40 let ( $\mathrm{N}=478)$. (b) Ze studie „Manželství, práce a rodina", která byla realizována v listopadu roku 2005 na reprezentativním souboru osob ve věku 20-40 let $(\mathrm{N}=2546)$. Sběr dat pro oba výzkumy provedla agentura SC\&C. ${ }^{6}$ Výsledky jsou srovnatelné, nebot' příslušné otázky byly kladeny identickým způsobem.

\subsection{Očekávané počty dětí}

Na velikost fenoménu jedináčkovství můžeme usuzovat z ukazatele, který nazýváme očekávaná konečná plodnost. Jak napovídá název, je obdobou konečné plodnosti, jež je standardním demografickým ukazatelem, který říká, kolik dětí připadá na jednu ženu na konci jejího reprodukčního období. Námi zavedená předpokládaná konečná plodnost je indikátorem, který je konstruován z výběrových dat. Vypočítá se jako součet dvou údajů, které ve výzkumu získáme na základě odpovědí na dvě otázky: jednak o počtu dětí, které již respondent má, jednak o počtu dětí, které by ještě chtěl mít v budoucnu. Je tedy konstruktem, který sestává z již existující komponenty a dále z komponenty poněkud nejisté. Proto ono adjektivum „očekávaná".

Podívejme se nejdříve, jak je očekávaná konečná plodnost rozložena v letech 2001 a 2005. . V roce 2001 byl průměrný očekávaný počet dětí, které ženy v průběhu své reprodukce porodí, 2,08 dítěte. Podle odpovědí z výzkumu v roce 2005 se

\footnotetext{
${ }^{5}$ Tato studie byla součástí mezinárodního srovnávacího výzkumu Population Policy Acceptance II, který byl proveden ve 14 evropských zemích.

${ }^{6}$ V obou případech byl koordinátorem výzkumu Ladislav Rabušic a jeho tým.

7 Podíl žen, které měly jedno dítě a které si nebyly jisté, zdali si přejí další, byl $19 \%$ v roce $2001(\mathrm{~N}=163)$. V roce 2005 to bylo $22 \%(\mathrm{~N}=290)$.
} 
Graf 3. Struktura očekávané konečné plodnosti žen ve věku 20-40 let v ČR v r. 2001 a v r. 2005 (podíl žen s uvedeným počtem dětí)

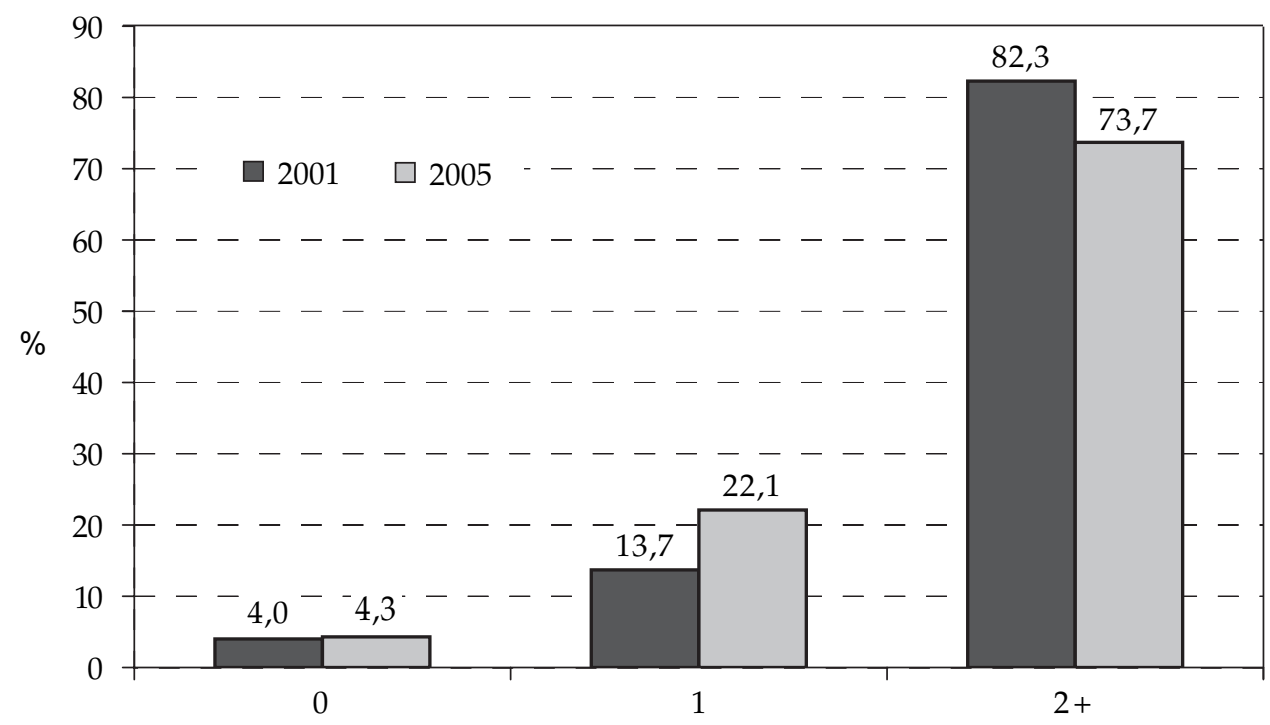

Zdroj: vlastní výpočty pro ČR z datového souboru PPA II a MPR 2005.

průměr snížil na 1,86. Struktura žen podle počtu dětí v obou letech je zobrazena v grafu 3. Vidíme v něm, že zde dochází k jisté proměně.

Podíl plánovitě bezdětných žen zůstal v obou srovnávaných obdobích na stejné úrovni a pohyboval se na úrovni 4 \%. K podobným údajům došly i Hamplová, Rychtaříková a Pikálková [2003: 87]. Podle jejich výzkumných dat z roku 1997 plánovalo nemít žádné dítě 4 \% českých žen. ${ }^{8}$ Tyto výsledky tak napovídají, že pokud by to záleželo pouze na ženách, Česku by výrazná bezdětnost v nejbližších desetiletích nijak výrazně nehrozila.

Proměna ale nastala u očekávané jednodětnosti. Podíl žen, u nichž lze předpokládat, že na konci své reprodukční kariéry budou mít pouze jedno dítě, byl $14 \%$ v roce 2001, do roku 2005 se zvýšil na 22 \%, což není nepodstatný rozdíl. Tento výsledek chápeme jako další z indikátorů, že se v Česku zásadně proměňuje populační klima. Dvaadvacetiprocentní podíl žen, které očekávají, že budou mít během svého pouze jedno dítě, je srovnatelný s hodnotami, které jsme nalezli v datech ze sčítání u konečné plodnosti žen ve věku 35 let.

\footnotetext{
${ }^{8}$ Data pocházejí z české části mezinárodního komparativního výzkumu Family and Fertility Survey (FFS). Vzorek obsahoval ženy ve věkové kategorii 15-44 let, šetření provedl Český statistický úřad.
} 
Tabulka 2. Struktura žen podle očekávaného počtu dětí (řádková \%) a podle věkových skupin v roce 2001 a 2005

\begin{tabular}{lrrrrrrrrrr}
\hline \multirow{2}{*}{ Věk } & \multicolumn{2}{c}{$\mathrm{n}$} & & Žádné dítě & Jedno dítě & Dvě a více dětí $\begin{array}{c}\text { Očekávaná } \\
\text { konečná } \\
\text { plodnost }\end{array}$ \\
\cline { 2 - 11 } & 2001 & 2005 & 2001 & 2005 & 2001 & 2005 & 2001 & 2005 & 2001 & 2005 \\
\hline $20-29$ & 133 & 601 & 1,2 & 3,0 & 8,4 & 24,7 & 90,4 & 72,3 & 2,03 & 1,83 \\
$30-40$ & 169 & 682 & 6,5 & 5,3 & 18,5 & 20,1 & 75,0 & 74,6 & 1,97 & 1,89 \\
\hline
\end{tabular}

Zdroj: vlastní výpočty pro ČR z datového souboru PPA II a MPR 2005 - vážené soubory.

Abychom našim datům ještě lépe rozuměli, ukažme si, jak se liší očekávaná konečná plodnost u mladších žen (ve věku 20-29 let a u žen starších (30-40 let). Údaje jsou zaznamenány v tabulce 2 .

Z těchto výběrových dat vyplývá, že v roce 2005 - ve srovnání s rokem 2001 - především výrazně stoupl podíl plánovitě jednodětných žen v mladší věkové skupině (20-29 let), a to z 8 na $25 \%$. Podíl jednodětných žen ve starší věkové skupině zůstal v podstatě beze změn a pohyboval se kolem $20 \%$. Podstatným zjištěním je také skutečnost, že zatímco v r. 2001 to byly starší ženy, u nichž jsme mohli na konci reprodukčního období očekávat pouze jedno dítě, v roce 2005 se očekávaný porod pouze jednoho dítěte objevuje u žen mladších.

Jak je na tom Česká republika v evropském kontextu? Jelikož máme data z mezinárodního výzkumu Population Policy Acceptance II (viz poznámku 4), jsme schopni v rámci zúčastněných zemí na tuto otázku odpovědět. Přináší ji graf 4 . Česká republika patřila v roce 2001 se svými 14 \% žen, u nichž se dá s jistou pravděpodobností předpokládat, že porodí během svého reprodukčního období pouze jedno dítě, k zemím se spíše nižším podílem. Společně se západními zeměmi SRN, Mad'arskem a Slovinskem jsme vytvářeli určitý "středoevropský klastr" se $14-15 \%$ podílem žen rozhodnutých mít jen jedno dítě. K zemím s více než $20 \%$ podílem jedináčkovství patří Rakousko (37 \%), dále východní země SRN, Belgie a Litva. Naopak pod 10\% podílem jedináčkovství byly Polsko, Finsko, Nizozemí a Estonsko.

Rozhodování o určitém počtu dětí je samozřejmě závislé na věku ženy a na skutečnosti, kolik dětí v době dotazování již má. Soustředíme-li svou pozornost na jedno dítě, dostaneme údaje, které jsou zobrazeny v tabulce 3. Uvádíme jen data z výzkumu v roce 2005, v roce 2001 při tomto třídění byly počty respondentek už př́liš malé.

Ve věkové skupině 20-29letých žen z těch, kteří ještě nemají žádné dítě, plánuje jedno dítě $24 \%$, zatímco ve věkové skupině 30-40letých to je $18 \%$. Mladé ženy jsou z tohoto hlediska častěji rozhodnuté pro jednodětnost. Stejně tak mlad- 
Graf 4. Očekávaná konečná plodnost jednoho dítěte v některých evropských zemích u žen ve věku 20-40 let, rok 2001-2002

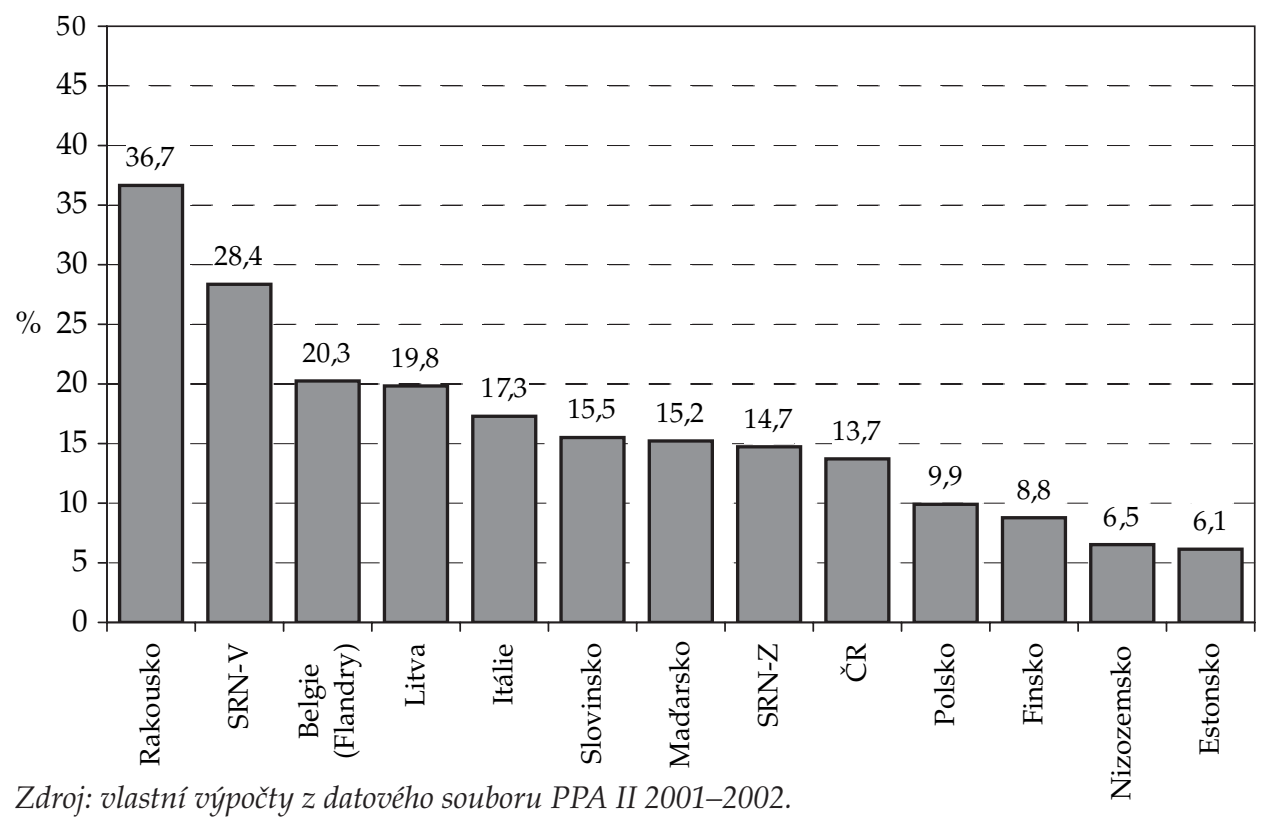

ší ženy, které již jedno dítě mají, jsou častěji než starší ženy rozhodnuty nemít další dítě, a zůstat tak pouze u jednoho (v poměru 58 : 36 \%).

Výsledky z roku 2005 jsou tak potvrzením trendu, který již byl zaznamenán v západních evropských zemích, a obracejí dosud existující poznatky. V dřívějších výzkumech populačního klimatu totiž mladší věkové skupiny obvykle očekávaly a plánovaly vyšší počty dětí než skupiny starší. V posledních letech, jak zaznamenali Goldstein, Lutz a Testaová [Goldstein, Lutz, Testa 2003], je tomu naopak. Lutze a Skirbekka [Lutz, Skirbekk 2005] to vedlo k představení hypotézy o pasti nízké fertility (low fertility trap hypothesis), kterou pak ještě rozpracovali s Testaovou [viz Lutz, Skirbekk, Testa 2005]. Jejich hypotéza tvrdí, že v Evropě může docházet ke kontinuálnímu poklesu počtu porodů. Podle nich jsou ve hře vzájemně se podporující tři mechanismy: demografický, to je snižování potenciálních počtů matek, které povedou ke snižování počtu narozených; sociologický, který způsobuje, že představy o ideálním počtu dětí v nejmladších kohortách se snižují, což je efekt nízké plodnosti, kterou kolem sebe vidí; a konečně ekonomický, založený na hypotéze relativního př́ijmu Richarda Easterlina [Easterlin 1987], která předpokládá, že plodnost je výsledkem aspirací a očekávaného příjmu - u mladých kohort se aspirace zvyšují, ale očekávaný př́ijem se snižuje. Tyto tři procesy povedou podle Lutze, Skirbekka a Testaové k sestupné spirále v počtu 
Tabulka 3. Plánování jednoho dítěte podle počtu současných dětí a věkových skupin (řádková \%), 2005

\begin{tabular}{lcc}
\hline Věk & $\begin{array}{c}\text { Počet } \\
\text { současných dětí }\end{array}$ & Očekávané 1 dítě \\
\hline $20-29$ & 0 & 24 \\
& 1 & 58 \\
$30-40$ & 0 & 18 \\
& 1 & 36 \\
\hline
\end{tabular}

Pozn. Dopočet do $100 \%$ v řádcích tvoří plány na žádné dítě nebo na 2 a více dětí.

Zdroj: datový soubor MPR 2005 - vážený soubor.

narozených, tedy $\mathrm{k}$ tomu, co již pojmenoval - v podobném duchu - Chesnais [1998] jakožto exponenciální spirálu úbytku populace.

Našim zjištěním o vyšším podílu plánovaných jedináčků v mladší věkové skupině žen odpovídají také údaje o průměrném počtu dětí, které lze hypoteticky v těchto dvou věkových skupinách očekávat (viz poslední dva sloupce v tabulce 2). V obou věkových skupinách došlo v roce 2005 ke snížení hodnot tohoto ukazatele, mladší věková skupina pak neočekává (a neplánuje) vyšší průměrný počet dětí než skupina starší.

Pokud by dnešní české třicátnice až čtyřicátnice měly konečnou plodnost na úrovni 1,82-1,96, nebot' takový je 95\% interval spolehlivosti pro průměr 1,89 dětí (v tabulce 2), a pokud by dnešní dvacátnice až třicátnice měly konečnou plodnost 1,77-1,89 (interval spolehlivosti pro průměr 1,83), nebyl by to vůbec špatný výsledek a relativně značný podíl žen anticipujících narození pouze jednoho dítěte bychom brali na vědomí jen jako zajímavý fakt. Otázkou je, jaká bude skutečnost.

\subsection{Charakteristika žen, které očekávají, že budou mít jedno dítě}

Podívejme se nyní, jaká je struktura žen, u nichž lze očekávat, že budou mít pouze jedno dítě, podle základních sociodemografických charakteristik. Uvádí ji tabulka 4.

Dvourozměrné tříděnínaznačuje, žepředpokládanou jednodětnost můžeme očekávat spíše u svobodných a rozvedených, dále u žen se základním vzděláním (vysokoškolačky nejméně často, ty ale budou mít pravděpodobně nejvyšší podíl bezdětnosti), u žen z rodin s nejnižším příjmem (27 \%), u žen bydlících ve velkoměstě (30\%), u žen, které nemají žádného sourozence, a jsou tedy z rodin jedináčků (30 \%), a konečně u žen, které nejsou členkami žádné církve.

Tuto charakteristiku, která by mohla dělat dojem typologie, však musíme brát s rezervou. Mnohé vztahy dvourozměrného třídění jsou ovlivněny půso- 
Tabulka 4. Předpokládaná struktura výsledného počtu dětí u žen podle vzdělání, rodinného stavu a členství v církvi; data z roku 2005 (řádková \%)

\begin{tabular}{|c|c|c|c|}
\hline & 0 dětí & 1 dítě & $2+d \ddot{e} t \hat{\imath}$ \\
\hline Rodinný stav: Svobodná ${ }^{+}$ & 7,7 & 25,2 & 67,1 \\
\hline Vdaná & 1,9 & 17,6 & 80,5 \\
\hline Ukončené manželství & 2,9 & 30,8 & 66,3 \\
\hline Vzdělání: Základní & 2,7 & 25,8 & 71,5 \\
\hline SŠ bez maturity & 4,2 & 21,3 & 74,6 \\
\hline SŠ s maturitou & 3,3 & 22,9 & 73,8 \\
\hline VŠ & 8,1 & 16,8 & 75,1 \\
\hline Př́ijem domácnosti: Do 14 tis. Kč & 3,7 & 27,4 & 68,8 \\
\hline $14001-20000$ & 5,1 & 19,5 & 75,4 \\
\hline $20001-27000$ & 3,1 & 16,5 & 80,5 \\
\hline $27001+K \check{c}$ & 6,5 & 20,6 & 72,9 \\
\hline Velikost místa bydliště: malá vesnice & 2,3 & 19,5 & 78,2 \\
\hline malé město & 4,0 & 20,1 & 75,9 \\
\hline středně velké město & 2,7 & 21,2 & 76,1 \\
\hline velké město & 8,9 & 30,4 & 60,7 \\
\hline Počet sourozenců: Žádný & 14,0 & 29,9 & 56,1 \\
\hline Jeden & 3,0 & 23,9 & 73,1 \\
\hline Dva & 4,2 & 17,5 & 78,3 \\
\hline Tři a více & 1,5 & 20,5 & 78,0 \\
\hline Členka církve: Ano & 2,9 & 16,4 & 80,7 \\
\hline $\mathrm{Ne}$ & 4,5 & 23,3 & 72,2 \\
\hline Celkem & 4,3 & 22,1 & 73,7 \\
\hline
\end{tabular}

Pozn.: + Zahrnuje i nesezdaná soužití.

Zdroj: vlastní výpočty z datového souboru MPR 2005.

bením intervenujících proměnných (např. velký podíl u žen z nízkopř́ijmových rodin, u nich lze očekávat pouze jedno dítě, je jistě ovlivněn tím, že je mezi nimi mnoho žen se základním vzděláním, které také nejčastěji předpokládají jedináčka atd.). Prozkoumejme proto nyní efekt čistého působení jednotlivých proměnných na očekávanou jednodětnost prostřednictvím modelu binární logistické regrese. Závisle proměnnou jsme v souladu s naším tématem dichotomizovali tak, že hodnoty 1 nabývaly případy, kdy bylo možné očekávat jednodětnosti, hodno- 
ty 0 pak ty, jejichž očekávaný počet dětí byl 2 a více. Z tohoto kódování je vidět, že jsme z analýzy záměrně eliminovali ženy, které nemají a nepřejí si ani jedno dítě. Důvodem byla skutečnost, že záměrně bezdětné ženy jsou přece jen zvláštní skupinou a nás v naší analýze zajímá především, jak se liší ženy rozhodnuté mít pouze jedno dítě od žen, které mají více dětí než jedno. ${ }^{9}$ Do regresního modelu vstoupily všechny proměnné, které jsou v tabulce 4 . K nim jsme ještě připojili věk ženy. Výsledky analýzy, jež jsou uvedeny v tabulce 5, skutečně ukazují, že mnohé vztahy se proměnily.

Tak především, věk ženy nemá žádný čistý vliv ${ }^{10}$ na šanci, že žena očekává pouze jedno dítě (adjustovaný poměr šancí není statisticky významný.) Stejně tak nehraje roli v rozhodování o jednom dítěti př́ijem domácnosti. Hypotéza, že jedináčkovství je bud' výrazem bohatých domácností, které své jedno dítě mají jako dítě statusové, nebo alternativní hypotéza, že jedno dítě je výrazem toho, že domácnost si nemůže více dětí dovolit, tak není našimi daty podporována. Žádnou roli nehraje ani členství v církvi, bytł bychom mohli ve shodě s výsledky třídění druhého stupně očekávat, že členky církve (v souboru jich bylo 15 procent) budou chtít výrazně častěji konečný počet dětí vyšší než jedno. Čistý efekt této proměnné však nebyl v regresi nalezen.

A nyní proměnné, jejichž působení statisticky významné je. Jasnou roli v rozhodování se pro jednodětnost a také pro její realizaci hraje vzdělání. Podle našich dat ženy s nižším vzděláním než středoškolským mají ve srovnání s ženami s nejvyšším, to je vysokoškolským vzděláním, trojnásobně, resp. dvojnásobně vyšší šanci na to, že během svého života budou mít pouze jedno dítě. Ženy se středoškolským vzděláním se svou šancí na jednodětnost od vysokoškolaček neliší. Samozřejmě, pohybujeme se v oblasti předpokládaného počtu dětí - ženy s VŠ vzděláním začínají v současné době v Česku obtížně hledat vhodného partnera, odkládají početí do vyššího věku a pocitují velké náklady ztracených př́iležitostí, takže je možné, že nakonec také skončí jen u jednoho dítěte. Nicméně náš výsledek opětovně potvrzuje zjištění, ke kterému na základě analýzy dat z komparativního evropského výzkumu, jenž proběhl ve třinácti zemích Evropy v letech 2001-2002, dospěla Van Peerová s Rabušicem [Van Peer, Rabušic 2008], totiž že vysokoškolské vzdělání nebrání lidem v plánech na vyšší počet dětí.

Jasný vliv na přání mít pouze jedno dítě má velikost místa bydliště. Respondentky, které žijí v obcí menších než ",velké město" ${ }_{11}^{11}$ mají statisticky významně nižší šance na to, že budou mít jen jedno dítě. Působení tohoto ekologického fak-

\footnotetext{
${ }^{9}$ Dalším důvodem, proč jsme neprovedli binární logistickou regresi na bezdětných ženách, které plánují pouze jedno dítě, jak navrhoval/a anonymní recenzent/ka, je nízký počet respondentů (pouhých 73) v takto vytvořeném podsouboru.

${ }_{10}$ Čistý vliv je relativní výraz. Lépe by bylo říci „očištěný od vlivů ostatních proměnných, které vstoupily do regrese".

${ }^{11}$ Definice velikosti místa bydliště byla ponechána na respondentech. Odpovídali na otázku: ̌̌ekl(a) byste, že žijete 1 . v malé vesnici, nebo 2 . v malém, 3. středně velkém nebo 4. velkém městě?
} 
Tabulka 5. Adjustované šance (odds ratio) ukazující pravděpodobnost, že respondent bude mít pouze jedno dítě, podle vybraných charakteristik

\begin{tabular}{|c|c|c|}
\hline & B koef. & $\begin{array}{l}\text { Adjustovaný } \\
\text { poměr šancí }\end{array}$ \\
\hline Věk (kardinální proměnná): & 0,03 & 1,03 nesignif. \\
\hline \multicolumn{3}{|l|}{ Rodinný stav: } \\
\hline Vdaná & $-0,79$ & $0,45 * *$ \\
\hline Ukončené manželství & $-0,13$ & 0,88 nesignif. \\
\hline Svobodná ${ }^{+}$ & 0,00 (ref.) & ref. \\
\hline \multicolumn{3}{|l|}{ Vzdělání: } \\
\hline Základní & 1,15 & $3,15 *$ \\
\hline SŠ bez maturity & 0,73 & $2,07 *$ \\
\hline SŠ s maturitou & 0,66 & 1,94 nesignif. \\
\hline VŠ & 0,00 (ref.) & ref. \\
\hline \multicolumn{3}{|l|}{ Celkový příjem domácnosti: } \\
\hline Do 14 tis. Kč & 0,13 & 1,14 nesignif. \\
\hline $14001-20000$ & $-0,20$ & 0,82 nesignif. \\
\hline $20001-27000$ & $-0,28$ & 0,76 nesignif. \\
\hline $27001+K c ̌$ & 0,00 (ref.) & ref. \\
\hline \multicolumn{3}{|l|}{ Velikost mista bydliště: } \\
\hline malá vesnice & $-0,92$ & $0,40^{* *}$ \\
\hline malé město & $-0,60$ & $0,55^{*}$ \\
\hline středně velké město & $-0,89$ & 0,41 ** \\
\hline velké město & 0,00 (ref.) & ref. \\
\hline \multicolumn{3}{|l|}{ Členka církve: } \\
\hline Ano & $-0,01$ & 0,99 nesignif. \\
\hline $\mathrm{Ne}$ & 0,00 (ref.) & ref. \\
\hline \multicolumn{3}{|l|}{ Počet sourozenců: } \\
\hline Žádný & 0,93 & $2,53 *$ \\
\hline Jeden & 0,57 & 1,78 nesignif. \\
\hline Dva & 0,04 & 1,04 nesignif. \\
\hline Tři a více & 0,00 (ref.) & ref. \\
\hline Konstanta & $-2,09$ & $0,12 * *$ \\
\hline
\end{tabular}

${ }^{+}$Pozn.: Zahrnuje i nesezdaná soužití.

Zdroj: vlastní výpočty z datového souboru MPR 2005.

Poznámky: (ref.) = srovnávaná kategorie; nesignif. = statisticky nesignifikantní; * $=\mathrm{p}<0,05 ;{ }^{* *}=\mathrm{p}<0,01$

Charakteristiky modelu: Chí kvadrát je statisticky signifikantní (model s daty vysvětluje závisle proměnnou lépe než model pouze s konstantou), Hosmer-Lemeshowův test není signifikantní ( $\mathrm{p}>0$ 0,05), což znamená, že modelová data (regrese je vždy modelem) a reálná data se neliší. Podíl správně klasifikovaných případů byl $79,6 \%$, což je dobrý výsledek, nebot' rozdíl mezi skutečnými daty a daty odhadnutými z modelu byl nízký. Nagelkerkeho R2 = 0,1, což znamená, že model vysvětluje pouze $10 \%$ variance závisle proměnné. 
toru nelze vysvětlovat jinak než durkheimovsky. Typ lokálních sociálních vazeb, které se formují v malých a středně velkých sídelních jednotkách, vytváří klima, které plány na jedno a jen jedno dítě nepodporuje (což ale ještě neznamená, že reálná konečná plodnost nakonec na jedináčkovi neustrne).

V podobném duchu, jak jsme interpretovali působení předchozí proměnné, lze hovořit i o vlivu počtu sourozenců. Jak ukazuje regresní analýza, respondentky, které nemají žádného sourozence a jsou tedy jedináčky, mají 2,5krát vyšší šanci než respondentky s vyšším počtem dětí, že samy budou mít pouze jedno dítě. Některé rodinné vzorce, jak vidno, mají tendenci se sociálně reprodukovat.

Poslední kategorií, která prokázala statisticky významný vliv na očekávanou jednodětnost, je rodinný stav ,vdaná‘. Vdané ženy mají o 55 \% nižší šanci, že budou mít jedináčky, než ženy svobodné. ${ }^{12}$ Legitimizace vztahu sňatkem je tak, zdá se, prvkem, který od jednodětnosti s velkou pravděpodobností odvádí. ${ }^{3}$

\section{Závěry a diskuze}

V tomto článku jsme se zabývali fenoménem jednoho dítěte v rodině, jednodětností. V jeho úvodu jsme museli konstatovat, že české poznatky o tomto jevu v podstatě neexistují - nemáme ani demografické, ani sociologické statě, které by nám tento speciální rodinný útvar popisovaly a vysvětlovaly. Na základě našich úvah, dat a analýz si dovolujeme tvrdit, že u generací českých žen, které ukončí své reprodukční období v následujících dvou dekádách, je možné se značnou pravděpodobností očekávat, že podíl žen, které porodí pouze jedno dítě, se bude pohybovat na úrovni 20-25\%. Netroufáme si zatím hodnotit, zdali to je podíl vysoký nebo nízký, z výběrových dat z roku 2001 nicméně lze předpokládat, že v Evropě budou země, které budou mít podíl i vyšší. Česká výběrová data ovšem naznačují, že mezi lety 2001 a 2005 měl podíl očekávané jednodětnosti mezi respondentkami reprezentativních výběrových šetření vzestupnou tendenci.

Naše analýza faktorů, které mohou vést české ženy k rozhodnutí zůstat ve své plodnosti pouze u jednoho dítěte, prokázala, že některé sociologické poznatky o vlivu struktury na jednání stále platí. Na mysli máme především zjištění o tom, že ženy pocházející z jednodětných rodin statisticky významně častěji počítají

${ }^{12}$ Do binární logistické regrese jsme zařadili místo rodinného stavu proměnnou partnerský vztah (to je, zdali respondentky žily v době výzkumu se stálým partnerem). Ukázalo se, že ženy žijící s partnerem mají nižší šanci mít na konci svého reprodukčního období jedno dítě než ty, které žijí bez partnera. Data nám neumožňují rozlišit mezi těmi, které žijí bez partnera dobrovolně, a těmi, které takto žijí nedobrovolně. Je možno vyslovit hypotézu, že ženy, které patří ke skupině žijících bez partnera dobrovolně, mohou mít odlišné reprodukční záměry i chování.

${ }_{13}$ Předpokládaná kauzalita by zde ale mohla být i obrácená. Svou roli by mohl sehrávat fakt, že ženy, které jsou více rodinně založené, chtějí také více dětí, takže mají vyšší pravděpodobnost, že uzavřou sňatek (za tuto připomínku děkujeme jednomu z anonymních recenzentů). 
s tím, že samy budou mít zase jedináčky, a že sociálně ekologické prostředí malých sídel má svơj vliv na rozhodování o tom, že ženy nebudou mít pouze jedno dítě.

Některé dosavadní poznatky ovšem platit přestávají. Podstatný je ten o vzdělání žen a očekávaném počtu dětí. Ukazuje se, že ve výsledcích po aplikaci postupů vícerozměrné analýzy ženy s nejvyšším vzděláním už zdaleka nejsou ty, které by si systematicky přály a očekávaly nejnižší počty dětí. ${ }^{14}$ Konkrétně v našem př́ípadě vyšší vzdělání nikterak nezvyšovalo šance na touhu zůstat celoživotně jen s jedním dítětem. Podobně neplatí, že církevní afiliace může být faktorem, který redukuje plány na jedináčkovství, a že tedy ženy nábožensky založené se v tomto ohledu neliší od žen, které na náboženský život napojeny nejsou. Tato zjištění mimo jiné ukazují, jak je důležité, aby se statistická analýza v sociálních vědách nespokojovala pouze s těmi nejjednoduššími postupy, nebot' ty mohou produkovat zkreslené výsledky (nepravé statistické vztahy), které při užití náročnějších postupů neobstojí. ${ }^{15}$

Naši analýzu jednodětnosti, kterou jsme předvedli v tomto článku, považujeme pouze za první krok, po němž by měly následovat další. Měli bychom udělat podobnou analýzu pro mužskou část našeho souboru a měli bychom také zjistit, do jaké míry na jedináčkovství působí vzájemné interakce mezi manželi či partnery, které jak ukázal Voas [2003], by mohly hrát důležitou roli. Data k tomu v našem souboru máme.

Měli bychom se také - nebo někdo další - pustit do úlohy, která by vzala v úvahu jednodětnost záměrnou a jednodětnost nezáměrnou vzniklou jakožto výsledek snížené biologické plodnosti. Můžeme totiž očekávat, že s posouváním prvních porodů do vyššího věku žen a mužů a $\mathrm{z}$ důvodů působení různých faktorů, které mohou způsobovat neplodnost mužů a žen, bude v Česku přibývat párů, které ani navzdory velkým pokrokům v reprodukčních možnostech medicíny nebudou schopny počít, donosit a porodit více než jedno dítě. Otázka dobrovolného a nedobrovolného jedináčkovství je tak - po vzoru dobrovolné a nedobrovolné bezdětnosti - dalším z témat, jemuž by se česká populační studia měla věnovat.

LADISLAV RABUŠIc je profesorem brněnské katedry sociologie Fakulty sociálních studii Masarykovy univerzity a nyní také děkanem této fakulty. Svưj badatelský zájem soustřed’uje předevšim na problematiku populačních studii a na otázky hodnotových proměn. Je autorem desítek statí nebo kapitol v knihách publikovaných jak doma, tak i v zahraničí

\footnotetext{
${ }^{14}$ Podporu k tomuto výroku lze hledat např. u van Peerové [van Peer 2002], která na mezinárodních datech z výzkumu FFS ukázala, že ženy s nejvyšším vzděláním nechtějí mít nejmenší počty dětí. Testaová a Toulemon [Testa, Toulemon 2006] našli ve Francii pozitivní vztah mezi vzděláním a ideální velikostí rodiny - vzdělanější ženy si přejí více dětí a jsou v mnohem menších počtech pro bezdětnost než ostatní kategorie.

${ }^{15}$ Nicméně tyto zkreslené výsledky se stávají součástí diskurzu a zakládají interpretační mýty.
} 
nebo prezentovaných na zahraničnich sociologických nebo demografických konferencích. Z českých časopisů publikuje hlavně v Sociologickém časopise / Czech Sociological Review a v Demografii. Je autorem monografie o př́činách a efektech populačního stárnutí (Česká společnost stárne), editoval knihu Česká společnost a senioři, vydal monografii nazvanou Kde ty všechny děti jsou? o př́činách nízké plodnosti v ČR. Nízká plodnost a populační politika jsou témata, jimž se v současnosti věnuje především.

Beatrice-Elena Chromková Manea pracuje od roku 2005 na Fakultě sociálních studií v Brně a jejím výzkumném Institutu pro výzkum reprodukce a integrace společnosti jako odborná pracovnice. Zabývá se populačními studiemi, především tematikou nízké plodnosti, v níž se orientuje na problematiku jednodětnosti. Dále se věnuje problematice skloubení práce/zaměstnání a rodiny. V loňském roce publikovala mimo jiné jako spoluautorka kapitolu o preferenční teorii v knize T. Sirovátky (ed.) Rodina, zaměstnání a sociální politika, která byla podkladem pro tuto demografickou stat'.

\section{Literatura}

Avdeev, A. 2001. "The extent of the fertility decline in Russia: is the one-child family here to stay?" [on-line] Př́spěvek přednesený na IUSSP Seminar International Perspectives on Low Fertility: trends, theories and politics. Tokyo, 21.-23. března [cit. 2. 8. 2007]. Dostupné z: <http://demography.anu.edu.au/Publications/ConferencePapers/IUSSP2001/ PaperAvdeev.doc $>$.

Bongaarts, John. 2001. „Fertility and reproductive preferences in post-transitional societies." Population and Development Review 27 (Supplement): 260-281.

Bracher, M., G. Santow. 1991. „Fertility Desires and Fertility Outcomes." Journal of the Australian Population Association 8 (1): 33-49.

Cliquet, Robert et al. 1992. „The 1991 Fertility and Family Survey in Flanders. Framework and Questionnaire." CBGS Working document $n^{\circ}$ 82. Brussels: CBGS.

Dudley, L. P., T. Fablo. 1990. „Academic performance and personality trates of Chinese children: ,onlies' versus others." American Journal of Sociology 96 (2): 433-451.

Easterlin, R. A. 1987. Birth and Fortune: The Impact of Numbers on Personal Welfare. Chicago: University of Chicago Press.

Falbo, T., L. P. Dudley. 1993. „The academic, personality and physical outcomes of only children in China." Child Development 64 (1): 18-35.

Frejka, T., J.-P. Sardon. 2007. „Cohort birth order, parity progression ratio and parity distribution trends in developed countries." Demographic Research [on-line] (16): 315-374 [cit. 2. 8. 2007]. Dostupné z: <http://www.demographic-research.org/ Volumes/Vol16/11/>.

Goldstein, J., W. Lutz, M. R. Testa. 2003. „The emergence of sub-replacement family size ideals in Europe." Population Research and Policy Review 22 (5-6): 479-496.

Hagewen, K. J., S. P. Morgan. 2005. „Intended and ideal family size in the United States, 1970-2002." Population and Development Review 31 (3): 507-527.

Hakim, C. 2003. „A New Approach to Explaining Fertility Patterns: Preference Theory.“ Population and Development Review 29 (3): 349-374.

Hamplová, D. 2000. „Postoje k manželství a rodičovství.“ Pp. 67-98 in L. Fialová, D. Hamplová, M. Kučera, S. Vymětalová. Představy mladých lidí o manželství a rodičovství. Praha: Sociologické nakladatelství. 
Hamplová, D., J. Rychtaříková, S. Pikálková. 2003. České ženy: Vzdělání, partnerstoí, reprodukce a rodina. Praha: Sociologický ústav AV ČR.

Chesnais, J. C. 1998. „Below-Replacement Fertility in the European Union (EU-15): Facts and Policies, 1960-1997." Review of Population and Social Policy (7): 83-101.

Jefferies, J. 2001. „A reluctance to embrace the one-child family in Britain?" Příspěvek přednesený na konferenci EUROSCO The Second demographic Transition in Europe. Bad Herrenalb, 23.-28. června.

Laufer, D. 1999. Enfants uniques. Des petites familles sous le regard des autres. Paříž: Bayard Editions.

Lutz, W., V. Skirbekk. 2005. „Policies addressing the tempo effect in low-fertility countries." Population and Development Review 31 (4): 699-720.

Lutz, W., V. Skirbekk, M. R. Testa. 2005. „The Low Fertility Trap Hypothesis: Forces that may lead to further postponement and fewer births in Europe." European Demographic Research Papers [on-line] (4) [cit. 2. 8. 2007]. Dostupné z: <http://www.oeaw.ac.at/vid/ download/edrp_4_05.pdf >.

Monnier, A. 1987. „Projets de fécondité et fécondité effective: une enquête longitudinale." Population 42 (6): 819-842.

Možný, I. 1991. Proč tak snadno... Některé rodinné důvody sametové revoluce. Praha: Sociologické nakladatelství.

Noack, T., L. Østby. 1985. „Fertility expectations: a short-cut or dead-end in predicting fertility?" Scandinavian Population Studies 7: 48-59.

Noack, T., L. Østby. 2002. „Free to choose - but unable to stick to it?“ Pp. 103-116 in E. Klijzing, M. Corinj (eds.). Dynamics of Fertility and Partnership in Europe. Volume 2. New York and Geneva: United Nations.

Polit, D., T. Falbo. 1987. „Only children and personality development: a quantitative review." Journal of Marriage and the Family 49 (2): 309-325.

Quesnel-Vallée, A., S. P. Morgan. 2003. „Missing the target? Corespondence of fertility intentions and behaviour in the U.S." Population Research and Policy Review 22 (5-6): 497-525.

Rabušic, L. 1987. „Několik poznámek k populačnímu vývoji v Číně.“ Demografie 29 (3): 262-269.

Rabušic, L. 1988. „Ještě k populačnímu vývoji v Číně.“ Demografie 30 (3): 275-276.

Rychtaříková, J. 2003. „Diferenční plodnost v České republice podle rodinného stavu a vzdělání v kohortní perspektivě." Pp. 41-83 in D. Hamplová, J. Rychtaříková, S. Pikálková. České ženy: Vzdělání, partnerství, reprodukce a rodina. Praha: Sociologický ústav AV ČR.

Sobotka, T. 2003. „Změny v časování mateřství a pokles plodnosti v České republice v 90. letech." Demografie 45 (2): 77-87.

Sobotka, T. 2006. „Bezdětnost v Ceské republice.“ Pp. 60-78 in D. Hamplová, P. Šalamounová, G. Šamanová (eds.). Životní cyklus. Sociologické a demografické perspektivy. Praha: SOÚ AV ČR.

Testa, M. R., L. Toulemon. 2006. „Family Formation in France: Individual Preferences and Subsequent Outcomes." Vienna Yearbook of Population Research 2006: 41-75.

Van Peer, Ch. 2002. „Desired and realized fertility in selected FFS-countries.“ Pp. 117-142 in M. Macura, G. Beets (eds.). Dynamics of Fertility and Partnership in Europe: Insights and Lessons from Comparative Research. Vol. 1. New York, Geneva: United Nations.

Van Peer, Ch., L. Rabušic. 2008. "Shall we witness an upturn in European fertility in the near future?" In D. Avramov, C. Hoehn, I. Kotowska. People, Population Change and Policies: Lessons from the Population Policy Acceptance Study. Springer (v tisku).

Voas, D. 2003. "Conflicting Preferences: A Reason Fertility Tends to Be Too High or Too Low." Population and Development Review 29 (4): 627-646. 
Westoff, C. F. 1990. „Reproductive intentions and fertility rates.“ International Family Planning Perspectives 16 (3): 84-89.

\section{Výzkumy}

Family and Fertility Survey (FSS), 1997

Mladá generace, 1997

Populační politika a veřejnost, 2001

Population Policy Acceptance II (PPA II), datový soubor, 2001

Žena, práce rodina, datový soubor, 2005 


\section{Sociologické studie/Sociological Studies ه Sociologický ústav AV ČR, v.v.i.}

\section{AKTUÁLNĚ V PRODEJI:}

2006:11 Věda jako věc veřejná: vědní politiky a média

Karel Čada, Alice Červinková, Marcela Linková, Dana Řeháčková, Tereza Stöckelová

$\mathrm{Na}$ základě expertních rozhovorů provedených na podzim roku 2005 tato publikace predstavuje procesy, které vědu a výzkum v současné společnosti ovlivňují - důraz na ekonomické aspekty vytváření znalosti a komerční využití výsledků, snaha o zachování tradičního vnímání vědy jako oddělené sféry, kterou kontrolují pouze výzkumné komunity, fungování novinářu jako překladatelů vědy společnosti, nikoli kritického hlasu, který by naopak vědě překládal či předkládal různorodé veřejné zájmy a konfrontoval ji s nimi. Jde o kritické zhodnocení těchto procesủ a jejich zasazení do širších evropských a globálních trendů. Autoři/rky chtějí poukázat na to, že změny v oblasti VaV probíhají v ČR a v Evropě současně, jsou předmětem sporů a vyjednávání a nemaji „tady“ ani „tam“ předem rozhodnutý výsledek. Rozsah textu je 75 stran, cena je 111 Kč bez DPH.

2006:10 Menšinová problematika v ČR: komunitní život a reprezentace kolektivních zájmů (Slováci, Ukrajinci, Vietnamci a Romové)

Yana Leontiyeva (ed.), Petra Ezzeddine-Lukšíková, Tomáš Hirt, Marek Jakoubek, Jiří Kocourek, Lucia Pažejová

Čtyři kapitoly textu byly vypracovány jako podkladové studie věnované národnostem a populacím, jejichž prítomnosti v ČR si nelze nevšimnout. Jedná se o Slováky, Ukrajince, Vietnamce a Romy. Hlavním cílem těchto poněkud pestrých studií je zmapovat situaci vybrané komunity nebo populace v ČR. Kapitoly o Slovácích, Ukrajincích a Vietnamcích jsou zaměřené především na studium současného komunitního života a rủzných aktivit uvnitř jednotlivých skupin, sdružování se v národnostních a krajanských organizacích a zájmových spolcích, které deklarují reprezentaci zájmů určité části menšinové nebo migrační komunity. Texty jsou založené na analýze dostupných výsledků kvalitativních a kvantitativních výzkumů a relevantních odborných studií, na textové obsahové analýze menšinového tisku a na kvalitativním výzkumu strategií menšinových organizací. Záměrem těchto informačně obsažných textů je přiblížit situaci vybraných menšin a migrantů v ČR jak odborné, tak i laické veřejnosti. Rozsah textu je 95 stran, cena je 123 Kč bez DPH.

\section{6:7 Sociální kapitál. Koncepty, teorie a metody měření}

\section{Jiři Šafr, Markéta Sedláčková}

Studie predstavuje koncept sociálního kapitálu, který se explicitně v sociálních vědách objevuje až od konce osmdesátých let, prestože implicitně byl zkoumán v sociologii již od počátku sedmdesátých let, jako zdroje zakotveného v sociálních sítích. V důsledku enormního rozmachu empirického studia sociálního kapitálu se tento pojem v současnosti vyznačuje existencí mnoha různorodých pojetí. Publikace přináší podrobný přehled pojmů, teoretických konceptů a typologií. Zevrubně a kriticky se věnuje přístupům P. Bourdieu, J. Colemana, N. Lina, R. Putnama a G. Beckera. Pozornost je věnována také specifikům sociálního kapitálu v postkomunistických zemích a zejména vývoji jeho studia v české sociologii. Druhá část studie se věnuje různým prístupům k měření rozdílných forem sociálního kapitálu. Rozsah textu je 93 stran, cena je 199 Kč bez DPH.

Objednávky prijímá a vyřizuje:

Tiskové a ediční oddělení, Sociologický ústav AV ČR, v.v.i., Jilská 1, 11000 Praha 1, tel. +420 222221 761, fax +420222 220 143, e-mail: sreview@soc.cas.cz http://studie.soc.cas.cz/ 